\title{
Evaluation the levels of Plasma Interleukins (IL-8, IFN- $\gamma$, IL-10) in Preeclamptic Pregnancies
}

\author{
Suaad A. Brakhas* Amna N.Jassim** \\ Received 6, December, 2009 \\ Accepted 30, May, 2010
}

Abbass M.Rahmah***

\begin{abstract}
:
This study is to evaluate plasma levels of several cytokines in preeclamptic pregnancies compared to those of healthy pregnancies.

Ninety pregnant women with preeclampsia (37 mild \& 53 severe) and thirty healthy pregnant women were enrolled in the study. Blood samples were taken and plasma levels of IL-8, IL-10, and IFN- $\gamma$ were measured by enzyme-linked immunosorbent assay (ELISA).

Preeclamptic women and their severe cases but not mild cases had significantly $(\mathrm{P}<0.05)$ increased levels of plasma IL-8, and IFN- $\gamma$ as compared with healthy pregnancies. By contrast, plasma levels of IL-10 was significantly $(\mathrm{P}<0.05)$ increased in healthy pregnant women as compared to all groups of preeclampsia. Preeclampsia is associated with an imbalance between pro-inflammatory cytokines (IL-8, IFN- $\gamma$ ) and anti-inflammatory cytokines (IL-10), and these support our suggestion of altered immune response in preeclampsia.
\end{abstract}

Key word: preeclampsia, immune response, cytokines

\section{Introduction:}

Preeclampsia (Toxemia of pregnancy) is one of the most common medical complications, that occurs in $3-5 \%$ of pregnancies and is a major cause of maternal and fetal morbidity and mortality with $15-20 \%$ in developed countries, and also is a leading cause of preterm birth and intrauterine growth retardation [1,2].

Preeclampsia is a multisystemic disorder involving the placenta, liver, kidneys, blood, and the neurological and cardiovascular systems [3]. The symptoms of this multisystemic disorder, which appear during the second and third trimester of pregnancy are caused by the increased vasoconstriction, which result in maternal hypertension, decreased uteroplacental blood flow, edema, proteinuria, abnormal clotting, liver and renal dysfunctions[4,5].

*Allergy Specilized Center

** Dept. Biology Science College for women/ Baghdad University.

*** Mustinsseria University/ Natioual center for Diabetes. 
The composition of immunomodulitory milieu, specifically the presence and amount of various cytokines in the sera of pregnant women may lend insight into the invivo regulation of preeclampsia associated condition. Several studies have reported abnormal levels of cytokines in women with preeclampsia, but the pattern of cytokine expression and a possible role in disease pathogenesis remains controversial [10].

In contrast to normal pregnancy, there are indication of increased inflammatory responses and also an immune deviation toward Th1 in the established preeclamptic pregnancy [11]. Robert et al [12] was one of the first to suggest that mediators released from the preeclamptic placenta are responsible for endothelial damage. Also an altered immune response and defective trophoblast invasion may play a key role in the development of preeclampsia [13]. The most immunological findings are the activation of both innate and adaptive immune system. Activated neutrophils, monocytes, and NK cells initiate inflammations which induce endothelial dysfunction and activated $\mathrm{T}$ cells may support inadequate tolerance during pregnancy [14]. Furthermore, the cytokine profile of women with preeclampsia is consistent with a cell mediated immune response that utilizes neutrophils, macrophages, and $\mathrm{CD}^{+}$Th1 cells as a defense mechanism against microbial infections. As a result elevated inflammatory cytokines and the oxidative burst of phagocytic cells persist resulting in vascular oxidative stress during preeclampsia $[15,16]$. Also, the immuno-regulatory system is down regulated in preeclampsia and persistent inflammation reduces regulatory $\mathrm{T}$-function, therefore the systematical immuno-activation may be one cause of this disease [14].

So the aim of the study is to evaluate the levels of proinflammatory cytokines (IL-8, IFN- $\gamma$ ) and anti-inflammatory cytokines (IL10) in the plasma of preeclamptic pregnancies.

\section{Material and Methods:}

This study was carried out at the Obstetric Department of Baghdad Teaching hospital and in the immunology department of the Teaching laboratories of medical city from May 2008 to May 2009. The patients were classified into three groups; 37 mild preeclampsia(group 1) with mean age 30.03 years, 53 sever preeclampsia (group 2) with mean age 28.85 years and 90 total preeclampsia (group 3) with mean age 29.33 years, and 30 apparently healthy pregnant women as control (group 4) with mean age 27.07 years. The diagnosis of preeclampsia was established in accordance with the American College of Obstetrics and Gynecology definition[17]. The healthy pregnancy was diagnosed on the basis of clinical, biochemical, and ultrasound findings and none of the patients had preexisting hypertensive disorders or any renal, hepatic, or hematological diseases, and had received no medication.

From each subjects included in the study, $3 \mathrm{ml}$ of maternal blood were taken by venous puncture and drawn into 5-mL tubes containing lithium heparin (Venoject, Terumo Europe $\mathrm{NV}$, Leuven, Belgium). The tubes were centrifuged at 1000 r.p.m for 5 minutes; the plasma was collected and stored at -20 until use. The concentrations of interleukins were measured using enzyme-linked immunoassays (ELISA) kit according to manufacturer's instructions. All immunoassay kits were purchased 
from Biosource Europe S.A Systems. The albuminuria was measured by dipstick test. Results are expressed as mean \pm standard error $(\mathrm{X}$ \pm SE). The significance of the difference between the values from different groups is determined using one way analysis of variance (ANOVA) (F-test). A level of $\mathrm{P}<0.05$ is defined as statistically significant [18].

\section{Results:}

The Demographic and obstetric features of the two groups (maternal age, gestational week and mean systolic and diastolic blood pressure at the time of sample collection are shown in Table 1. ALL the preeclamptic patients have albumin in urine $\leq+1$, while no one of the control group have albuminuria.

There was no significant $(\mathrm{P}>0.05)$ difference in maternal age, gestational week between the two groups. There were a significant $(\mathrm{P}<0.001)$ increase in mean systolic and diastolic blood pressure, $142 \pm 0.71 \& 91.89 \pm 0.53$ $\mathrm{mmHg}$ in group 1 , and $167.74 \pm 1.63$ $\& 112.45 \pm 1.40 \mathrm{mmHg}$ in group 2 , and $157.44 \pm 1.64 \& 104.00 \pm 1.37 \mathrm{mmHg}$ as compared with controls, . The mean \pm SE plasma levels of Interleukin-8 $(\mathrm{pg} / \mathrm{ml})$, IFN- $\gamma(\mathrm{IU} / \mathrm{ml})$, Interleukin-10 $(\mathrm{pg} / \mathrm{ml})$ in the preeclampsia group (total) were $101.42 \pm 5.09,6.54 \pm 0.78$ and $10.61 \pm 1.00$ respectively, while the mean $\pm \mathrm{SE}$ plasma levels of Interleukin- 8 (pg/ml), IFN- $\gamma$ (IU/ml) and Interleukin- $10(\mathrm{pg} / \mathrm{ml})$ in severe preeclamptic group were $109.12 \pm$ $7.01,6.78 \pm 1.08$ and $9.28 \pm 1.12$ respectively, The mean \pm SE plasma levels of Interleukin-8 (pg/ml), IFN- $\gamma$ (IU/ml), Interleukin-10 (pg/ml) in mild preeclampsia group were $86.63 \pm 5.00$, $5.19 \pm 0.87$ and $13.05 \pm 1.90$ respectively, and the mean \pm SE plasma levels of Interleukin- $8(\mathrm{pg} / \mathrm{ml})$, IFN- $\gamma(\mathrm{IU} / \mathrm{ml})$ and Interleukin- $10(\mathrm{pg} / \mathrm{ml})$ in control group were $82.53 \pm 4.73,3.43 \pm 0.80$ and $15.57 \pm 1.87$ respectively (Table 2).

Table 1. Demographic and clinical characteristics of patients with preeclamptic and healthy pregnant women (Mean $\pm \mathrm{SE})$.

\begin{tabular}{|c|c|c|c|c|c|}
\hline Characteristics & (1) MPE (N=37) & (2) SPE (N=53) & (3) TPE (N=70) & (4)Control $(\mathrm{N}=20)$ & P-Value \\
\hline Maternal age (years) & $30.03 \pm 1.14$ & $28.85 \pm 0.98$ & $29.33 \pm 0.74$ & $27.07 \pm 1.12$ & $\begin{array}{l}\text { (1)(4) NS } \\
\text { (2)(4) NS } \\
\text { (3)(4) NS } \\
\text { (1)(2) NS }\end{array}$ \\
\hline Gestational age (weeks) & $34.43 \pm 0.68$ & $35.72 \pm 0.60$ & $35.19 \pm 0.45$ & $33.63 \pm 1.00$ & $\begin{array}{l}\text { (1)(4) NS } \\
\text { (2)(4) NS } \\
(3)(4) \mathrm{NS} \\
\text { (1)(2) NS }\end{array}$ \\
\hline $\begin{array}{c}\text { Systolic blood pressure } \\
(\mathbf{m m H g})\end{array}$ & $142.70 \pm 0.71$ & $167.74 \pm 1.63$ & $157.44 \pm 1.64$ & $108.00 \pm 1.99$ & $\begin{array}{l}(1)(4)<0.001 \\
(2)(4)<0.001 \\
(3)(4)<0.001 \\
(1)(2)<0.001\end{array}$ \\
\hline $\begin{array}{c}\text { Diastolic blood pressure } \\
(\mathrm{mmHg})\end{array}$ & $91.89 \pm 0.53$ & $112.45 \pm 1.40$ & $104.00 \pm 1.37$ & $74.50 \pm 1.05$ & $\begin{array}{l}(1)(4)<0.001 \\
(2)(4)<0.001 \\
(3)(4)<0.001 \\
(1)(2)<0.001 \\
\end{array}$ \\
\hline Albumin in urine & $1+$ & $2+4+$ & $1+4+$ & 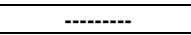 & ---------- \\
\hline
\end{tabular}

MPE $=$ Mild preeclampsia; SPE $=$ Severe preeclampsia; TPE $=$ Total preeclampsia $;$;S = Non Significant $\quad ; \mathrm{P}<0.00=$ Highly significant

Table2. Comparsion the plasma levels of interleukins (IL-8, IL-10, IFN- $\gamma$ ) between the studied groups (mean $\pm \mathrm{SE}$ ).

\begin{tabular}{|c|c|c|c|c|c|}
\hline Interleukins & (1)MPE(N=24) & (2)SPE(N=46) & (3)TPE(N=70) & (4)Control(N=20) & P-Value \\
\hline Interleukin -8 (pg/ml) & $86.63 \pm 5.00$ & $109.12 \pm 7.06$ & $101.41 \pm 5.09$ & $82.53 \pm 4.73$ & $\begin{array}{c}(1)(4) \mathrm{NS} \\
(2)(4)<0.01 \\
(3)(4)<0.05 \\
(1)(2)<0.05\end{array}$ \\
\hline Interferon $-\gamma(\mathrm{IU} / \mathrm{ml})$ & $5.19 \pm 0.87$ & $6.78 \pm 1.08$ & $6.54 \pm 0.78$ & $3.43 \pm 0.80$ & $\begin{array}{c}(1)(4) \mathrm{NS} \\
(2)(4)<0.05 \\
(3)(4)<0.05 \\
(1)(2) \mathrm{NS}\end{array}$ \\
\hline Interleukin- $10(\mathrm{pg} / \mathrm{ml})$ & $13.05 \pm 1.90$ & $9.28 \pm 1.12$ & $10.61 \pm 1.00$ & $15.57 \pm 1.87$ & $\begin{array}{l}(1)(4) \mathrm{NS} \\
(2)(4)<0.00 \\
(3)(4)<0.05 \\
(1)(2)<0.05\end{array}$ \\
\hline
\end{tabular}

NS = Non Significant Significant at the 0.05 level Significant at the 0.01 level 


\section{Discussion:}

Endothelial cell injury and dysfunction may play a central role in the pathogenesis of PE, this dysfunction associated with PE characterized by an enhanced inflammatory response and altered cytokine production [19]. IL-8 (known previously as neutrophil attractant activation protein), is produced by many different cell types such as monocytes, macrophages, endothelial cells, fibroblasts, and neutrophils [20].IL-8 plays major roles in the inflammatory process by recruiting neutrophils into sites of inflammation and infection [20].

IL-8 was significantly
increased in patients with severe preeclampsia, but not in mild and control groups. These findings suggest that endothelial activation resulting in the increased production of chemokines in women with preeclampsia. Also it may be due to many pathological conditions such as apoptosis, inflammation, neutrophil activation, endothelial cell damage and dysfunction, and increased endothelial permeability.

This was in accordance with the works of some, but not all investigators. Jonsson et al [10] \& Kocyiqite et al [21] found increased levels of IL-8 in the serum of preeclamptic women than those of healthy pregnancies. Scott et al [22] found 2.5 fold increased plasma IL-8 levels in severe preeclamptic women compared with healthy pregnant women.

The present results also reports significantly $(\mathrm{P}<0.05)$ increased levels of plasma IFN- $\gamma$ in preeclamptic pregnancies and their severe groups. It is known that IFN- $\gamma$ enhances cytotoxic activation of $\mathrm{T}$ - lymphocyte and NK cells, activates macrophages and phagocytosis, and induce proinflammatory cytokine expression, therefore increased concentration of IFN- $\gamma$ in pregnancy can be potentially harmful [23]. IFN- $\gamma$ is a proinflammatory cytokine secreted in the uterus during early pregnancy. It is abundantly produced by uterine natural killer cells in maternal endometrium but also by the trophoblast in some species. In normal pregnancy, IFN- $\gamma$ plays critical roles that include initiation of endometrial vasculature remodeling, angiogenesis at implantation sites and maintenance of the decidual (maternal) component of the placenta, deviation in these processes are thought to contribute to serious gestational complications, such as fetal loss, or preeclampsia[24].

However, excessive amount of IFN- $\gamma$ in conjugation with TNF- $\alpha$ and IL-1 can lead to apoptosis of trophoblasts [25, 26]. In an inflammatory environment, macrophages secrete high levels of IL12 that stimulate IFN- $\gamma$ secretion by natural killer cells, thereby inhibiting angiogenesis [27]. The results are consistent with the finding of ArriagaPizano et al [28], who reported significantly higher concentration of IFN- $\gamma$ in maternal peripheral blood of preeclamptic women compared to normotensive ones. As a result, higher concentration of IFN- $\gamma$ may be due to other sources of cytokine such as decidual or endothelial cells. On the other hand, another study found no difference in serum levels of IFN- $\gamma$ between normal and preeclamptic pregnant women [10] .The authors also speculated that this could be explained by known paracrine action of $\mathrm{T}$ - cell cytokines, secreted cytokine are rapidly bound to receptors on neighboring cells and excessive levels in preeclampsia or normal pregnancy may be thus captured the site of secretion, resulting in similar serum levels in both groups. In preeclamptic pregnancies, IFN- $\gamma$ production are 
significantly raised, it is therefore likely that this production is central to the exaggerated inflammatory response and endothelial cell dysfunction of the maternal disease [29].

IL-10 is an inhibitor of activated macrophages and dendritic cells and thus involved in the control of innate immune reaction and cell mediated immunity [30]. IL-10 is an important anti-inflammatory cytokine in pregnancy that inhibits upregulation of matrix metallproteinase- 2 and -9 and promotes the termination of Th1 inflammatory rejections against the fetal placental unit and their abnormalities may be associated with the inadequate placental development in preeclampsia $[13,31]$. There are several lines of evidence indicating that IL-10 involved in maintenance of pregnancy by suppressing the production of cytokines by cytotoxic $\mathrm{T}$ cells and macrophages [32]. Previous works shown conflicting levels of IL10, their levels have been shown to increase, decrease, or remain unchanged in women with preeclampsia [33, 34, 35].

The results in agreement with the study of Borekci et al. [36] who found that the mean concentration of IL-10 in pregnant women with preeclampsia and their severe group was significantly lower than those of controls. Coussons-Read et al [37] found that pregnant women experiencing high stress had lower levels of IL-10 than pregnant women reporting less stress, and their data suggested that stress exposure during pregnancy might indirectly increase the risk of pregnancy complications by either predisposing the immune system to infection or directly by increasing production of pro-inflammatory cytokines.

\section{Conclusion;}

It has been found that increased levels of IL 8, IFN- $\gamma$ and decreased levels of IL-10 in the plasma of women with severe preeclampsia. These findings suggest that severe preeclamptic women have higher plasma pro-inflammatory cytokines and reduced anti-inflammatory cytokines such as IL-10. Preeclamptic pregnant women in this study may indicate the presence of disturbance in immunological tolerance, disturbance in trophoblastic invasion and impaired placentation.

\section{References:}

1. Dekker, G. \& Robillard, P.Y. 2007. Preeclampsia: Is the immune maladaptation hypothesis still standing? J Reprod Immunol; 76:816.

2. Robert, J.M.; Pearson, G.; Gutler, J. \& Lindheimer, M. 2003. Summary of the NHLBJ working group on research hypertension during pregnancy. Hypertension; 41:437-45.

3. Wagnar, L.K. 2004. Diagnosis and management of preeclampsia. Am J Famil Phsi; 70(12):2317-2324.

4. James, D.K.; Steer, P.J.; Weiner, C.P. \& Gonik, B. 2006. High Risk Pregnancy: Management Option. Elsevier Sunders, $3^{\text {rd }}$ ed, pp: $772-$ 779.

5. Crombleholme, W.R. 2008. Obstetrics \& Obstetric disorders. In: Current Medical Diagnosis and Treatment, McPhee, S.L.and Papadakis, M.A.(Edt). McGrawHill,USA. pp: 673-675.

6. Shennan, A. 2007. Hypertensive disorders. In: Dewhursts Textbook of Obstetrics\& Gynecology,. Blackwell, $7^{\text {th }}$ ed,UK. pp: 227.

7. Jonsson, Y.; Matthiesen, L.; Berg, G.; Ernerudh, J.; Niemineri, K.; \& Ekerfelt, C. 2005.Indications of an altered immune balance in 
preeclampsia: a decrease in in vivo secretion of IL-5 \& IL-10 from blood mononuclear cells and in blood basophile counts compared with normal pregnancy. J Reprod Immunol ;66:69-84.

8. Gilbert, J.S.; Ryan, M.J.; Lamarca, B.B.; Sedeek, M.; Murphy, S.R. and Granger, J.P. 2008. Pathophysiology of hypertension during preeclampsia: Linking placental ischemia with endothelial dysfunction. Am. J. Phsiol. Heart. Circ Physiol; 294:H541-H550.

9. Cunningham, F.G.; Leveno, K.J.; Gilstrap, L.C.; Hauth, J.C.; Wenstrom, K.D.; Bloom, S.L. 2005. Williams Obstetrics.22 $2^{\text {nd }}$ ed, McGraw-Hill,USA. pp: 116-140.

10. Jonsson, Y.; Ruber, M.; Matthiesen, L.; Berg, G.; Nieminem, K. \& Sharma, S. 2006. Cytokine mapping of sera from women with preeclampsia and normal pregnancies. J Reprod Immunol; 70:83-91.

11. Suzuki, S. \& Ouchi, N. 2007. T helper $1 / T$ helper 2 cell immunity in preeclamptic twin pregnancy. $\mathbf{J}$ Nippon Med Sci; 74:434-436.

12. Roberts, J.M.; Taylor, R.N.; Musci, T.J.; Rodgers, G.M.; Hubel, C.A. \& Mclaughlin, M.K. 1989. Preeclampsia: An endothelial cell disorder. Am J Obstet Gynecol; 161(5):1200-4.

13. Matthiesen, L.; Berg, G.; Ernerudh, J.; Ekerfelt, C. \& Jonsson, Y.; Sharma, S. 2005. Immunology of preeclampsia. Chem Immunol Allergy; 89:49-61.

14. Saito, S.; Shiozaki, A.; Nakashima, A.; Sakai, M. \& Sasaki, Y. 2007. The role of immune system in preeclampsia. Mol Asp Med; 28:192-209.

15. Vural, P.; Saral, N.Y. \& Akgul, C. 2008. Plasma pro-inflammatory and anti-inflammatory cytokine levels in preeclampsia. J Ist Faculty Med; 71:9-13.

16. Lamarca, B.D.; Ryan, M.J. \& Granger, J.P. 2007. Pathophysiology of hypertension during preeclampsia: Role of inflammatory cytokines. Current Hypertension Review; 3:69-74.

17. ACOG Committee on Obstetric Practice. ACOG practice bulletin .2000. Diagnosis and management of preeclampsia and eclampsia. No.33, American Collage of Obstetricians and Gynecologists. Obstet Gynecol; 99:159-167.

18. Sorli, D.E. 1995. Medical biostatistical \& epidemiology: Examination \& board review, $1^{\text {st }}$ ed.Appleton\&Lange:47-88.

19. Cunningham, F.G. \& MacDonald, P.C. 2001. Hypertensive Disorders in Pregnancy. In: Williams Obstetrics, 21ed, McGraw-Hill, New York, pp.178-187,568-579.

20. Doan, T.; Melvold, R.; Viselli, S. \& Waltenbaugh, C. 2008. Lippincotts IIIustrated Reviws: Immunology .Lippincott Williams \& Wilkins, Philadelphia. pp; 55155.

21. Kocyigit, Y.; Atamer, Y.; Atamer, A.; Tuzcu, A. \& Akkus, Z. 2004. Changes in serum levels of leptin, cytokines, and lipoprotein in preeclamptic and normotensive pregnancies. Gynecol Endocrinol; 19(5):267-73.

22. Scott, K.; Takacs, P.; Scordalakes, C.; Walsh, S.; Gren, K. \& Peng, T. 2002. Increased endothelial chemoattractant protein-1 and interleukine-8 in preeclampsia. Obstet Gynecol; 100:706-14.

23. Darmochwal, D.; Leszczynska, B.; Rolinski, J. \& Oleszezak, J. 1999. $\mathrm{T}$ helper 1 - and $\mathrm{T}$ helper 2-type cytokine imbalance in pregnant women with preeclampsia. Eur $\mathbf{J}$ Obstet Gynecol Reprod Biol; 86:165-70. 
24. Murphy, S.P.; Tayade, C.; Askhar, A.A.; Hatta, K. \& Zhang, J.; AnneCroy, B. 2009. Interferon-Gamma in successful pregnancies. Biol Reprod; 80:848-859.

25. Moffett, A. \& Hiby, S.E. 2007. How dose the maternal immune system contribute to the development of preeclampsia? Placenta; 28:51-6.

26. Ashkar, A. A. \& DiSanto, J.P.; Croy, B.A. 2000. Interferongamma contributes to initiation of uterine vascular modification, decidual integrity, and uterine natural killer cell maturation during normal murine pregnancy. J Exp Med; 192:259-270.

27. Saito, S. \& Sakai, M. 2003. Th1 / Th2 balance in preeclampsia .J Reprod Immunol; 59(2):161.

28. Arriaga-Pizano, L.; JimenezZamudio, L.; Vadillo-Ortega, F. \& Martinez-Flores, A.; HerreriasCanedo, T. 2005. The predominant Th1 cytokine profile in maternal plasma of preeclamptic women is not reflected in the chorio-decidual and fetal compartments. J Soc Gynecol Inves; 12(5):335-342.

29. Sargent, I.L.; Borzychowski, A.M. \& Redman, C.W.G. 2007. NK cells and preeclampsia. J Reprod Immunol; 76:40-44.

30. Abbas, A.K.; Lichtman, A.H.; Pillai, S. 2007. Cytokines .In: Cellular and Molecular Immunology. Chapter $12,6^{\text {th }}$ ed, Sunders Elsevier, Philadelphia, pp: 267-300.

31. Rein, D.T.; Breidenbach, M.; Honscheid, B.; Friebe-Hoffmann, U.; Engel, H.; Gohring, U.J.; Uekermann, L.; Kurbacher, C.M. and Schondorf, T. 2003. Preeclampsia women are deficient of interleukin-10 as assessed by cytokine release of trophoblast cells in vitro. Cytokin;23:119-125.

32. Kamali-Sarvestani, E., Kiany, S.; Gharest-Fard, B. \& Robati, M. 2006. Association study of interleukin-10 and IFN-gamma gene polymorphisms in Iranian women with preeclampsia. J Reprod Immunol; 72:118-26.

33. Bakheit, K.H.; Bayoumi, N.K.; Eitom, A.M.; ALbashir, M.J. and Adam, I. 2009. Cytokine profiles in Sudanese women with preeclampsia. Hypertension .Preg; 28(2):224-229.

34. Sharma, A.; Satyam, A. \& Sharma, J.B. 2007. Leptin, IL-10 and inflammatory markers (TNF- $\alpha$, IL6, and IL-8) in preeclamptic, normotensive pregnant and healthy non-pregnant women. Am J Reprod Immunol; 58(1):21-30.

35. Mansouri, R.; Akbari, F.; Vogdjgani, M.; Mahboudi, F.; Kalantar, F.; Mirahmadian, M. 2007. Serum cytokines profiles in Iranian patients with preeclampsia. Iranian J Immunol; 4(3):179-185.

36. Borekci, B. \& Aksay, H.; Atakan, R.; Demircan, B.; Kadanali, S. 2007. Maternal serum interlukine10 , interleukin- 2 and interleukin-6 in preeclampsia and eclampsia. Am J Reprod Immunol; 58(1):56-64.

37. Coussons, R.; Okun, M.L.; Schmitt, M.P. \& Giese, S. 2005. Prenatal stress alters cytokines levels in a manner that may endanger human pregnancy. Psychosomatic Med; 67:625-631. 


\section{تقييم مستوى الحركيات الخلوية في بلازما النساء ذوات مقدمة الارتعاج}

عباس مهني رحمة ****

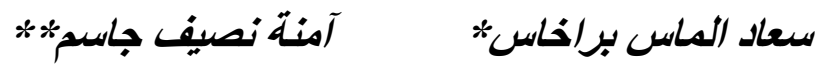

* * المركز التخصيصي للحساسية ـ دائرة صحة بغداد الرصافة.

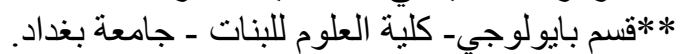

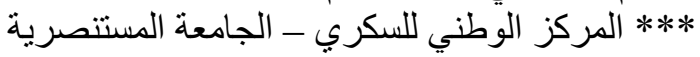

تضمنت هذه الدراسة تقييم مستويات كل من الحركيات الخلوية

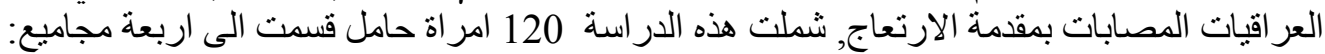

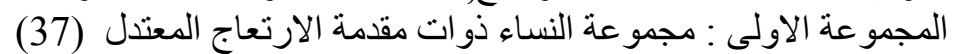

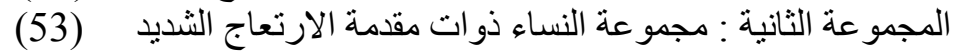

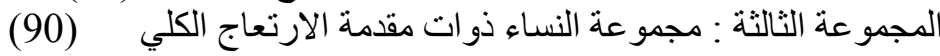

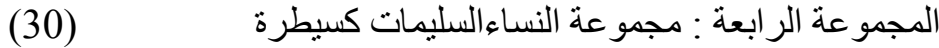

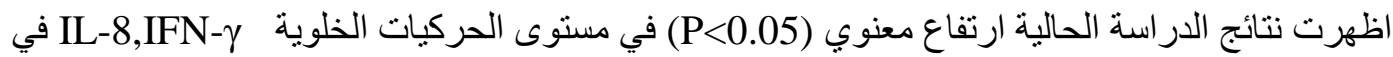

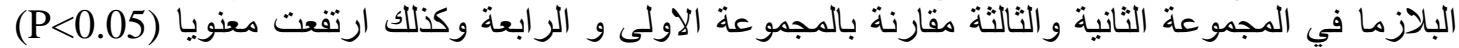

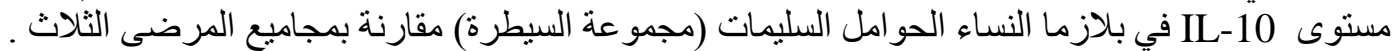

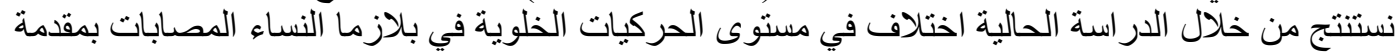

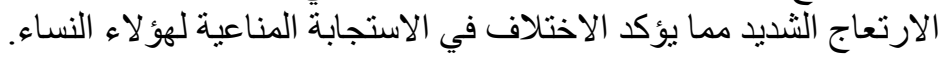

